\title{
血清カルシウムの臨床的研究
}

\author{
長崎大学医学部高岡内科（指導 高岡普人教授） \\ 金子重 敏

\section{STUDIES ON THE CLINICAL SIGNIFICANCE OF SERUM CALCIUM CONTENT}

\author{
Shigetoshi KanEKo \\ The First Department of Internal Medicine, \\ Nagasaki University School of Medicine (Director: Prof. Yoshito Takaoka)
}

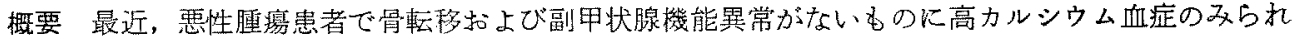
る症例が報告されて，従来の血清カルシウム調節機構にかんする考え力は再検討の必要に迫られてい る.乙かす, 各種疾患で血清総カルシウムの変動についての臨床的研究はき放めて少なく、さらに, カルシウムを透析性执よび非透析性に分けて测定した臨床報告は全くみあたらないようである。著者 はこの点に注目してカルシウム調節機構を検討する基礎として各種患者 504 例飞ついて血清カルシウ ムを測定した結果，総カルシウムの增娍する疾患について興味ある所見をえた．また総カルシウムが 一見変動しないと考えられる疾患でも透析性または非透析性（蛋白結合性）カルシウムが種々の変動 を示すことを認めた。例えば, 全身の消耗をきたすような急性㧊よび慢性肝炎, 肝硬変症, 癌, 肺結 核, 甲状腺機能九進症, 糟㲾病, 高血圧症, 消化性漬煬等では血清総カルシウムに著变がない場合で も, 透析性カルシウムが增加し, 非透析性カルシウムが減少しているが, Conn 症候群では透析性が 低下し非透析性には変動がなかつた。 また，血清䌏カルシウムと非透析性カルシウムの変動は，血清 蛋白，とくに血清アルブミンと正の相関を示したが，血清無機燐との間には相関を認めえなかつた。 このようなカルシウム変動の作用機転についても文献的考察を行なつた.
\end{abstract}

\section{I. 緒言}

生体におけるカルシウム(以下カと略す) 代謝 が副甲状腺ホルモンに支配されることはすでに 1908年 W.C. MeCallum ら火よつて知ら机ていた が，副甲状腺ホルモンが結晶の形で抽出されたの

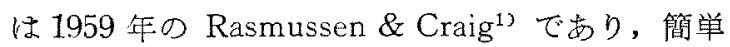
で信頼度の高い力测定法がないことと相まつて， この方面は他の内分泌系に比べて未知の点が多 い. Howard, Rasmussen ${ }^{2}$ は副甲状腺ホルモン が腸管からの力吸収と管尿細管の力再吸収を促 進, 骨加らの力放出を堌強するものと説明し, 副

本研究の要旨任昭和 35 年 11 月第 4 回日本生化学会九州 部会総会,ならびに昭和 37 年 10 月第 8 回日本生化学会九 州部会で発表した。
甲状腺ホルモンの過剩は血清力を増加するが，生 理的飞怔末梢のCaイオン濃度が逆飞副甲状腺ホル モンの分泌に影響する feedback mechanismを考 えている。

このよ5な見解で生休の力代謝は副甲状腺ホル モンで一応解決できたかにみ充たが，最近では， 副甲状腺，骨，腎に何ら異常を認めない Hodgkin 病, 癌, ザルコイドージス, Basedow 病などで高 力血症をさたす例や，副甲状腺機能杂進症と粹 炎, 消化性潰演などの合併例が報告され，從来の 副甲状腺ホルモンだけでは説明できない話題が提 供されつ〉おる。

一方，1871年 Pribam らは血清力に二つ以上の 
分画があることに気付き 1911 年 Rona \& Takahashi は透析性力と非透析性（蛋白結合性）力と を分離し, 透析性カはイオン化力と炭酸, クエン 酸, 苳酸の力塩からなり, 非透析性力《大部分が アルブミンと，一部は $\beta$-グロブリン执よび cephalin と結合し，健康人では一定の比率走保つてい ることを明らかにしだ、ざらに McLean \& Hastingは》1937年血清蛋白と非透析性力との間に 相関関係があることを指摘した。しかし透析性と 非透析性との平衡がいかに保九れているかについ ては想像の域を脱せず，各種矣患の透析性，非透 析性力代謝異常にかえする報告は全くみられな w.

したがつて著者は現段階でカ代謝を根本的に再 検討寸る手がかりとして，臨床面で血清総力，透 析性㧍よび非透析性力を测定することが重要な鍵 になると考克，各種患者と健康人について血清総 カを，またその半数については透析性抏よび非透 析性力を测定し，これらと血清総蛋白，無機燐と の相関関係について検討した，以下その概略を報 告する.

\section{II. 実験方法}

I. 被検者

表 1 に示す如く，健康な病院勤務者86例を対照

表 1. 血清力を测定した被検者 (XII/1959 X目/1963)の概要

\begin{tabular}{|c|c|c|c|c|}
\hline 種 類 & 年令付 & & $Z x$ & 3 \\
\hline 健虔者 & $19 \sim 62$ & $56(20)$ & $30(20)$ & 85640 \\
\hline 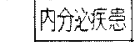 & $15-76$ & $4 /(3 /)$ & $4 /(30)$ & $82(61)$ \\
\hline 悪忙哣湯 & $23 \sim 96$ & $53(3 /)$ & $34(19)$ & $87(50)$ \\
\hline 腎疾荧 & $9-71$ & $25(10)$ & $19(10)$ & $44(20)$ \\
\hline 膠原 病 & $24 \sim 70$ & $6(2)$ & $11(6)$ & $17(8)$ \\
\hline 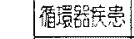 & $11-73$ & $57(16)$ & $32(8)$ & $89(24)$ \\
\hline 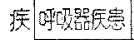 & $19 \sim 64$ & $21(7)$ & $6(2)$ & $27(9)$ \\
\hline 正游疾密 & $16-68$ & $6(6)$ & $7(4)$ & 13610 \\
\hline 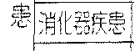 & $13 \sim 79$ & $82(43)$ & $28(9)$ & $110(52)$ \\
\hline 樎経疾㭧 & $|5 \sim 6|$ & $16(1)$ & $3(1)$ & $19(2)$ \\
\hline 兰の他 & $10-71$ & $11(8)$ & $5(3)$ & $16(11)$ \\
\hline 計 & $9 \sim 79$ & $3184156)$ & 186091 & 504247 \\
\hline 怠計 & & 3740176 & 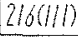 & 900287 \\
\hline
\end{tabular}

（）内透折性力を去測定した实笯
群とし，約 4 年間の本学病院外来和上び入院患者 455 例，市内公立病院入院患者 49 例，計 504 例の 各種奖患について，血清総力を測定し，5ち247 例については透析性扣よび非透析性力をも测定 し，血清総蛋白量，筫機燐と比較検討した，表中 の䛦断名はごく一部のものを除き生検, 腹腔鏡, 手術, 剖検で礁認されたものである.

II. 测定法

早朝空腹時に採血，直亏に血清を分猚する。透 析性力を測定する場合には外気の接触で血液 $\mathrm{pH}$ の低下によるカ增加”を防ぐため，採血した血液 は流動パラフィンで封入する必要がある。

(1) 血清総力

Clark \& Collip 变法 ${ }^{8)}$ を用い，血清 $1 \mathrm{cc}$ 儿苳酸 アンモニウムを加点，得た沈殿を稀アンモニヤ 水で洗浄し，残つた沈渣を約 1 規定の $\mathrm{H}_{2} \mathrm{SO}_{4}$ 液で 溶かし $1 / 200$ 規定 $\mathrm{KMnO}_{4}$ を用いて滴定した。滴定 の終点はわずかに微紅色を呈する点とし 単位は $\mathrm{mg} / \mathrm{dl}$ でホした.

その recovery testは婊 2 に示すよ 5 2.0， $4.0,6.0 \mathrm{mg} / \mathrm{dl}$ の力（焰光光度計用力標準液上り 作製)を加えた 15 例の被検者血清の実測值 測值に対して $1.9 \%$ 以内誤差で充分信頼でき ると考究た。

（2）血清透析性和よび非透析性力

Toksoy \& Eser 陽圧加圧法" ${ }^{92}$ により図 1 に示 す上5に，枝付きガラス管の両端を水銀圧力計と 送気バルブにそれそれれ接続した。つぎに下記のよ 5にして作製したコロジオン管中に血清 $1 \mathrm{cc}$ を流 動パラフィンで封入し空気がもれないよ5に各枝

表 2. 力涺定の recovery test

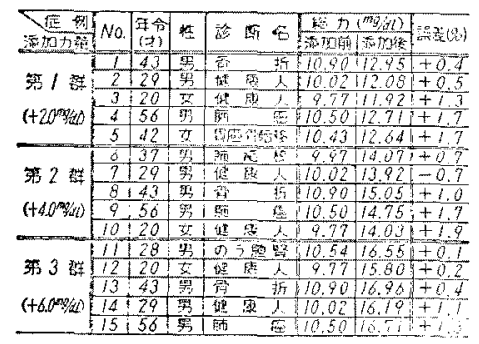


に固定し，これを5ccの純水を入れたスピッツグ ラスに漫し，水面と血清の面をそるえてスピッッ グラスを固定した。

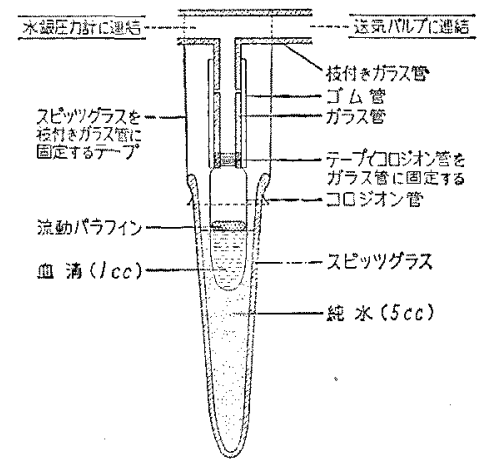

四 1. 佋清力透析装置

つぎに送気バルブより空気を送りコロジオン管 中の血清面比 $160 \mathrm{mmHg}$ の圧力が加わるようにし て7 時間透析した．スピッツグラス中の透析性力 には飽和葆酸アンモニウム $1 \mathrm{cc}$ を加え, 以下総力 と同様にして测定し，非透析性力心総力から透析 性力をひいて算出した。

コロジオン管は径 $8 \mathrm{~mm}$ 長さ $150 \mathrm{~mm}$ の試験管 底に径 $2 \mathrm{~mm}$ の小孔を第ち，この試駼管を市即の コロジン中にくり返し浸した㖟，空気中に放置 し，完全に乾燥する前に管周困のコロジオン膜に 切を入れて馀駼管より抜きとりコロジン管を作 製した。

表 3 に示すよ5に血清透析性力の reproducing test として同一椧体を 2 回測定した 15 例中 11 例 (No. 1〜11) では両者の差が0.22\%以下で, 最も

表 3 . 透析力 $の$ reproducing test

\begin{tabular}{|c|c|c|c|c|c|c|c|}
\hline \multicolumn{2}{|r|}{ 痘 } & \multicolumn{2}{|r|}{ 例 } & \multicolumn{3}{|c|}{ 暹梢性办 $(m g / d l)$} & \multirow{2}{*}{$\frac{1-f I}{17} \times 100$} \\
\hline No. & 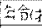 & 性 & 診 & $I$ & $\pi$ & $I-\bar{I}$ & \\
\hline 1 & 29 & 5 & 急性肝次 & 5.03 & 5.03 & 0 & 0 \\
\hline 2 & 61 & $y$ & 旺 造 聇 & 6.07 & 6.07 & 0 & 0 \\
\hline 3 & 33 & 2 & 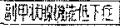 & 3.68 & 3.68 & 0 & 0 \\
\hline 4 & 65 & 3 & 䇫 & 3.77 & 3.77 & 0 & 0 \\
\hline 5 & 26 & 7 & 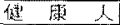 & 4.66 & 4.66 & 0 & 0 \\
\hline 6 & 19 & $2 \pi$ & 健 & 5.07 & 5.07 & 0 & 0 \\
\hline 7 & 30 & $i z$ & 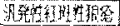 & 5.76 & 5.71 & 0.05 & 0.9 \\
\hline 8 & 15 & 5 & 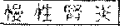 & 4.85 & 4.00 & 0.05 & 1.0 \\
\hline & 30 & 3 & Wh fit it & 5.20 & 5.15 & 0.05 & 1.0 \\
\hline 10 & 25 & 9 & 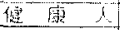 & 4.77 & 4.71 & 0.06 & 1.3 \\
\hline 11 & 26 & 2 & 18 & 4.77 & 4.71 & 0.06 & 1.3 \\
\hline 16 & 19 & 21 & 纽 度 & 4.66 & 4.56 & 0.10 & 2.2 \\
\hline 13 & 23 & 丽 & 霍 & 5.25 & 5.10 & 0.15 & 2.9 \\
\hline 14 & 43 & tx & 㫜 通 & 4.90 & 4.72 & 0.18 & 3.8 \\
\hline 15 & 24 & 兒 & 经 & 4.66 & 4.46 & 0.20 & 4.5 \\
\hline
\end{tabular}

差の大きかつた No. 15 でも $4.5 \%$ であり，充分 信頼できる测定法と考兄た。

（3）血清無機燐，総蛋白

無機燐は Fiske-Subbarow 法に上り日立分光光 度計を用い，総蛋白は日立屈折計を用いて测定し た.

\section{1. 健康者群}

\section{III. 実験成纈}

表 4 に示すよ5に多少年令に偏りがあるが，86、 例の総力は9.80土0.21 mg/dl $(9.33 \sim 10.36 \mathrm{mg} / \mathrm{dl})$ ， であつた。健康人の血清力值のばらつきが極めて 少ない点は疾患群に比べて特徴的であつた。

表 4. 踺康者の血涓力・総蛋白最・無機燐

\begin{tabular}{|c|c|c|c|c|c|c|c|}
\hline \multirow{2}{*}{ 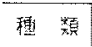 } & \multicolumn{2}{|c|}{ 例 数 } & \multirow{2}{*}{ 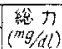 } & \multirow{2}{*}{ 造拍则 } & \multirow{2}{*}{ 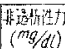 } & \multirow{2}{*}{ 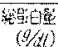 } & \multirow{2}{*}{ 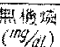 } \\
\hline & 男 & पर & & & & & \\
\hline If $10-190$ & $0(0)$ & $4(3)$ & 9.93 & 4.77 & 3.22 & 7.7 & 3.40 \\
\hline$\Leftrightarrow 2020.29$ & $40(5)$ & 28077 & 9.79 & 4.79 & 4.90 & 7.5 & 3.38 \\
\hline$=1130-39$ & $10(5)$ & $0(0)$ & $9.8 ?$ & 4.84 & 4.85 & 7.6 & 3.29 \\
\hline I. $40 \sim 49$ & 2 & 0 & 9.73 & - & - & - & - \\
\hline $\pm 500-59$ & 3 & 0 & 9.91 & - & - & - & - \\
\hline fellow & 1 & 0 & 9.03 & $\ldots$ & - & - & - \\
\hline 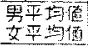 & $\begin{array}{l}513 \\
30\end{array}$ & $(20)$ & 9.86 & $\begin{array}{l}4.86 \\
4.78 \\
\end{array}$ & $\begin{array}{l}4.96 \\
4.88\end{array}$ & $\begin{array}{l}7.6 \\
7.5\end{array}$ & $\begin{array}{l}3.26 \\
3.49\end{array}$ \\
\hline 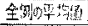 & 800 & (40) & $9.80 \pm 02$ & $4.82 \pm 0.2$ & $4.92 \pm 0.21$ & $2.6 \pm 0.3$ & 337037 \\
\hline
\end{tabular}

この中 40 例の透析性力に $4.82 \pm 0.20 \mathrm{mg} / \mathrm{dl}$ (4. $39 \sim 5.15 \mathrm{mg} / \mathrm{dl})$, 非透析性力 $4.92 \pm 0.21 \mathrm{mg} /$ dl $(4.45 \sim 5.37 \mathrm{mg} / \mathrm{dl})$ で, 透析性力は総力の 49.5 \%をしめている。

40 例の血清総蛋白量 $7.6 \pm 0.30 \mathrm{~g} / \mathrm{dl}(7.1 \sim 8.0 \mathrm{~g} /$ dl), 血清無機燐 $3.37 \pm 0.37 \mathrm{mg} / \mathrm{dl}(2.65 \sim 4.00 \mathrm{mg}$ /d1）であつた.

II. 各種疾患群

(1) 内分泌疾患

表 5 K示守上5に, 㓭甲状腺機能六進症 1 例で は血清総蛋白量が正常で血清総力, 透析性, 非透 析性のすべてが著明に增加し，副甲状腺機能低下 症 2 例では逆にこの3 者が皆著減している．甲状 腺機能六進症 20 例の総力平均值 は正常範团であ り，10.95mg/dl までのや〉高い值を示した4 例: では透析性力と無機橉が高かつたがX線所見で骨 変化は認めず，甲状腺炎は1例(No.26)を除けば 著変がなかつた：しかるに粘液水腫 1 例と Sheehan 特よび Cushing 症候群の各 2 例中 1 例は総 
表 5. 内分泌奖䔡の血清力・総蛋白量・烸機烧

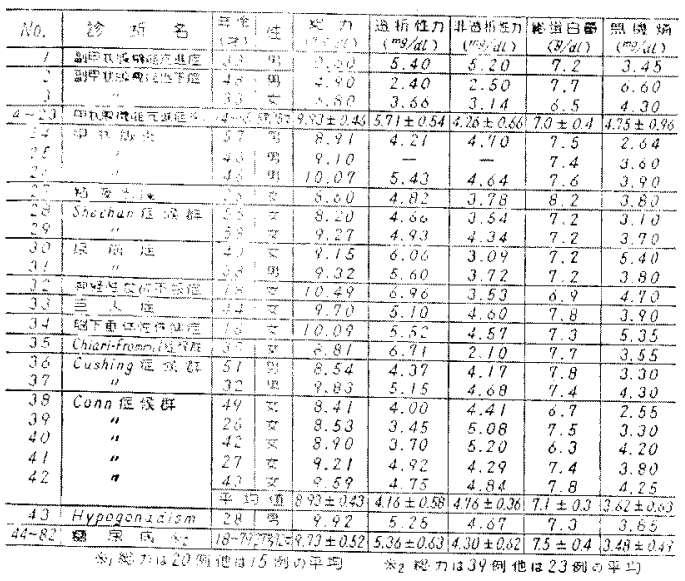

カ叔よび非透析性力が低下し，尿崩症，神経性 食欲不振症, Chiari-Frommel 症候群で唀析性 が增加し非透新性力方低下乙ている. Conn 症候 群では 2 例 (No.38,39) で総力, 3 例 (No. 38, 39，40）で透析性が減少している。䌅尿病39例で は非透析性力の低下がみられる。

つぎに䛦断上注意を要する副甲状腺譏能買常の

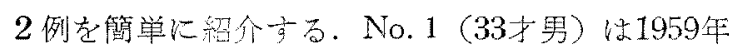
5 月頃より口渴，全身倦急感を訴兄慢性孯炎とし て治療され 1 年徭に法閶節痛, 意撞消失発作が时 時和こるようになり，1962年6月には四肢疬虬上 び背凊が加かつたが診㴹が確定しなかつた。1963 年 3 月原爆病院の骨のX線㭘查でのう腫状線維性 骨炎の所見が認められ，血清総力 $15.0 \mathrm{mg} / \mathrm{dl}$ ，热 壦燃 2. $4 \mathrm{mg} / \mathrm{dl}$, 原中力排泄量 $196 \mathrm{mg} / \mathrm{day}$, 尿 中無機燃 $208 \mathrm{mg} / \mathrm{day}$ があり潮く副甲状腺機能宇 進症と診断された。同年 5 月手術によつて $7.0 \mathrm{~g} の$ 副甲状腺腺腫さ摘出, 以㣪血清力, 無機燐は正常 值に復し, 上記症状も軽快した。

No.2(48才男) 社中学時代より時々雨手からはじ

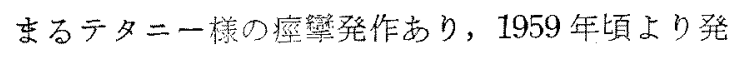
作が頻回強度となり当内科を訪れた。当時Trous一 seau 現象陽性, Chvostek 現象陰性, 肝機能, 腎機能，血糖梌查， ECG，電解質 ( Na 140, K4.32， Cl $101.8 \mathrm{mEq} / l$ ) い方机正常, 血清総力 4.90 , 透析性力 2.40 , 非透析性力 $2.50 \mathrm{mg} / \mathrm{dl}$, 血清無

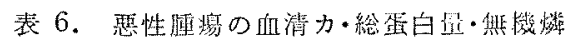

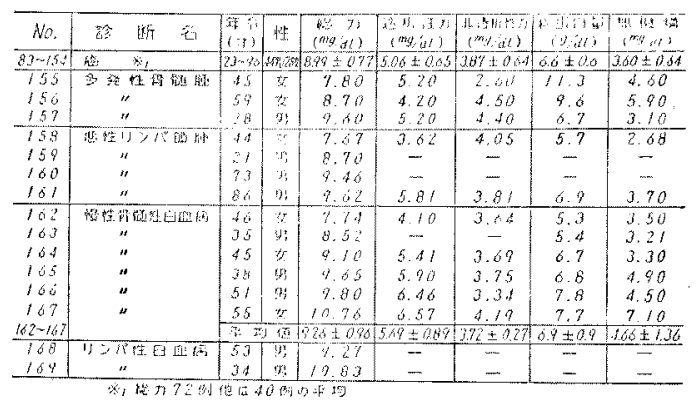

機獾 $6.6 \mathrm{mg} / \mathrm{dl}$ で, 尿中力排泄量 $64 \mathrm{mg} / \mathrm{day}$, 尿 中然機燐 $273 \mathrm{mg} / \mathrm{day}$ といずれも低值を示し, 副 甲状腺機能低下症と猃断された。程化力投与で軽 快した。

(2) 悪性腫瘍

表 6 に示すよ5に癌 72 例 (胃癌 37 , 肝癌 7 , 胆 道癌 7 , 肺癌 10 , 子宮癌 9 , 唉頭癌 1 , 乳癌 1) て は血清総蛋白量の低下と総力および非透析性力低 下との間に正の相関がみられたが血清然機權との 間には相関がみられなかつた。骨転移があつて も(胃癌，乳癌各 1 例，子宮癌 8 例）必ずし女血 清総力が高嗐を示すとは限らず，癌で高力血症を 示した 3 例中骨転移のある子宮癌 1 例 ( $11.10 \mathrm{mg}$ / d1)在除く肝およで肺癌の备 1 例では (10.50m/ d1) 剖検で骨整移, 副甲状腺異常が認められなか つた点で注目に值する。

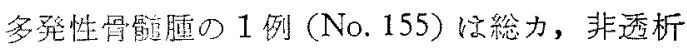
性力の低下が著明で，この減少は血清総蛋白量の 増加 $(11.3 \mathrm{~g} / \mathrm{d} 1)$ よりあアルブミンの低下と平行 することを示している。

瑟性、ンパ節腫3例では異常高値を示す例なく， ホジキン病 1 例 (No.158) ではカ 3 分画の低下が 著明で低蛋白血症も認められた。骨䯣性白血病で は統力が総蛋白量と平行して減少した 2 例 (No.

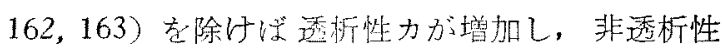
カが低下しているものが多かつた。

総力が $19.83 \mathrm{mg} / \mathrm{dl}$ と異常高值を示したリンパ 性白血病の1例（No.169）は1960年 1 月比上り頸 部リンパ節腫镺に気付き，これが急速に増大， 3 月末には全身に大小多数のリンパ節腪脹をられる 
よ5になり，高熱が加わつたために同年 4 月 4 日 当科に入院した.肝・脾腫脹し, 白血球数 17000 末 梢血液像では全視野に 2 個のリンパ芽紐胞を証明 した. 以後，高熱が弛張し充分の桧索もできない ま 4 月13日死亡した。剖檢の結果はリンパ性白 血病であり，副甲状鿟，骨に異常所見はみられな かつた。

（3）紫疾患

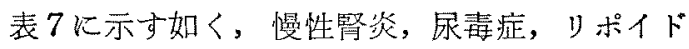
ネフローゼでは一般に血清総蛋白量, 総カ扮よび 非透析性力が低下し，透析性力も減少しているも のが多く，無機燐が增加していた。

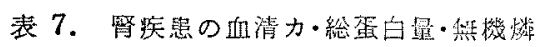

\begin{tabular}{|c|c|c|c|c|c|c|c|c|}
\hline No. & 竝断名 & Is & 性 & n & 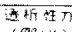 & 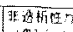 & W. & Ty \\
\hline $170-20$. & 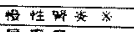 & $\frac{1-197}{|15-7|}$ & (2) & & 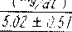 & & $\frac{(8,40)}{63 \pm 06}$ & 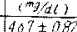 \\
\hline 204 & SR & 75 & i & 5.80 & 3.20 & 2.60 & 0.5 & 8.15 \\
\hline 206 & $"$ & ${ }_{57}^{30}$ & 3 & 0.30 & - & & 0.0 & 9.78 \\
\hline & " & 18 & 要 & $\begin{array}{l}7.07 \\
7.25\end{array}$ & 4.80 & $\begin{array}{l}2.47 \\
-\end{array}$ & 6.4 & 6.21 \\
\hline 208 & $"$ & 20 & 两 & 7.40 & 5.18 & 2.22 & 0.0 & $\therefore 10$ \\
\hline 210 & " & $\begin{array}{l}47 \\
24\end{array}$ & 然 & $\begin{array}{l}7.80 \\
9.20\end{array}$ & 3.79 & 4.01 & 7.0 & 17.29 \\
\hline 11 & 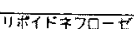 & & $F r$ & $x=1$ & $1 / 4+26$ & $3 / 2=0.2$ & $65 \pm 4$. & $30 \div 4 / 4$ \\
\hline & ब3 & $\frac{9}{54}$ & $\frac{\pi}{4}$ & & 0.58 & & 4.8 & 2.45 \\
\hline 213 & & 28 & 9 & 10.54 & 0.38 & 2.81 & $\begin{array}{l}3.7 \\
8.7\end{array}$ & 582 \\
\hline
\end{tabular}

慢性腎炎34例中 10例のネフローゼ加味踿炎では 特に血清総蛋白量 ( 6 例は $5.0 \mathrm{~g} / \mathrm{dl}$ 台), 総力 (7.30 $\sim 8.74 \mathrm{mg} / \mathrm{dl})$, 非透析性力 $(2.04 \sim 3.76 \mathrm{mg} / \mathrm{dl})$ の 低下はとくに強かつた。尿毒症 7例では総力およ び非透析性力低下はさらに著明であつたが，この 変化は血清総蛋白量の低下とそれぞれ正の相関を 認め血清無機燐との間には何ら相関を認めなかつ た。 その中でも尿毒症の1例(No. 204) では血 清総力 5.80 , 透析性 3.20 , 非透析性 $2.60 \mathrm{mg} / \mathrm{dl}$ であつたがテタニー発作, Chvostek 見象, Trousseau 現象等は全く認められなからた。

(4) 膠原病

表 8 の汎発性紅斑性狼瘔, 多発性関節リウマチ, 強皮症, 皮膚笳炎, 多発性笳炎は, 血清総蛋白量 が正常であるのに総力, 非透析性力が低下するす のがきわめて多く，透析性力，血清無機燐は著変 がなかつた。中でも汎発性紅斑性狼瘡 7 例の総力 の低下が著明で（測定した 2 例ではとくに非透析 性カが低下）あつたことは注目すべき所見と考え る。
表 8. 膠原病の血清カ・総蛋白量・無機燐

\begin{tabular}{|c|c|c|c|c|c|c|c|c|}
\hline No. & 診 数 五 & la & 性 & 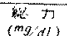 & 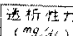 & 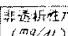 & 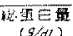 & 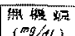 \\
\hline 214 & 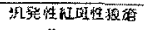 & 30 & t女 & $\frac{9.02}{8.02}$ & 4.57 & $\frac{3.45}{3.45}$ & 8.2 & \begin{tabular}{|l|l}
1.618 \\
.65
\end{tabular} \\
\hline 215 & $"$ & 49 & 里 & & & & & \\
\hline & $"$ & 24 & 女 & 8.17 & 4.75 & 3.42 & 8.6 & 4.01 \\
\hline 218 & 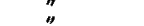 & 38 & 渵 & $\begin{array}{l}8.20 \\
9.75\end{array}$ & $=$ & $\overline{=}$ & 8.4 & 3.35 \\
\hline & " & 38 & 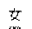 & 8.99 & 4.44 & 4.55 & 8.2 & $\begin{array}{l}3.00 \\
4.60\end{array}$ \\
\hline 220 & & 29 & & & & & & 3.66 \\
\hline 221 & 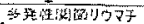 & 50 & 女 & 8,31 & 4.40 & 3.91 & 6.7 & $\frac{199 \pm 048}{400}$ \\
\hline & & 70 & 管 & 8.71 & & 2.70 & 6. & \\
\hline & & & 9 & 9.10 & 4.47 & 4.33 & & \\
\hline $\begin{array}{l}224 \\
225\end{array}$ & " & 55 & 要 & $\begin{array}{r}9.55 \\
10.00\end{array}$ & $=$ & & 8.0 & 3.67 \\
\hline & 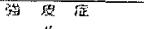 & 44 & \% & 8.63 & 4.89 & 3.74 & 8.1 & 4.55 \\
\hline 58 & 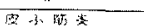 & 32 & $\frac{y}{32}$ & $\frac{70.32}{900}$ & & & $\frac{7.9}{9}$ & $2000+3$ \\
\hline 229 & 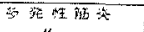 & 21 & 2 & 8.79 & 5.50 & 3.29 & $\frac{7.8}{8.2}$ & $\frac{4.90}{4.10}$ \\
\hline
\end{tabular}

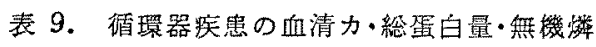

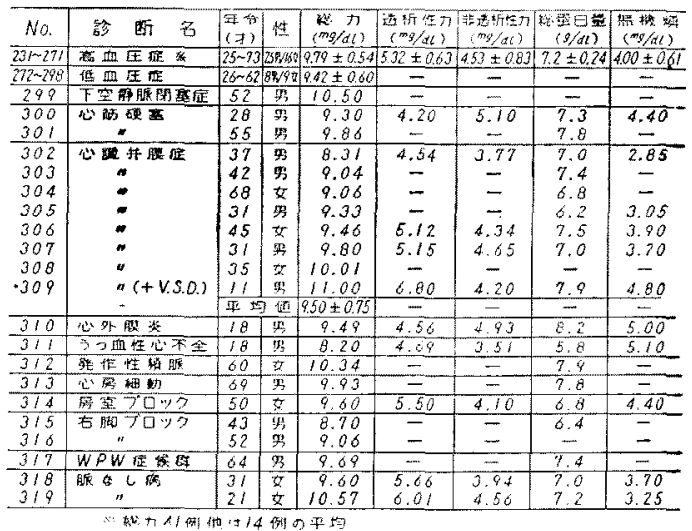

(5) 循環器疾患

表 9 に示すよ 5 に特に一定の変動を示さず血清 総蛋白 $5.8 \mathrm{~g} / \mathrm{dl}$ と低下したうつ血性心不全 (No. 311）の1例で総力と非透析性力の低下があり, 心臟弁膜症，右脚ブロックの各 1 例 (No. 302, 315）で総カが低下したが 総蛋白量の低下はなか つた。また心室中隔欠損症 兼僧䡠弁閉鎖 不全症 (No. 309) は総力 11.00 , 透析性力 $6.80 \mathrm{mg} / \mathrm{dl}$ の 異常高值を示し, 血清無機燐当 $4.8 \mathrm{mg} / \mathrm{dl}$ と高か つた。

(6) 呼吸器疾患

表10の如く，肺結核の総かはとくに变動なく， 透析性カが高く，非透析性カが低下していた。助

表 10 . 呼吸器矣患の血清力・総蛋白量·無機燐

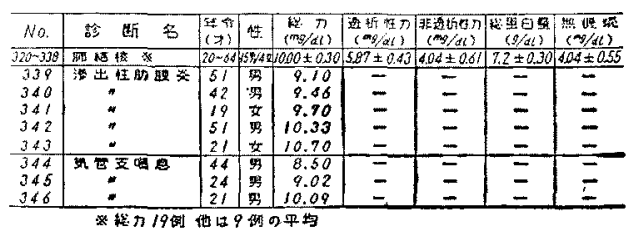


膜炎でも総力は変動せず，アレルギー突患である 気管支喘息では 3 例中 2 例で低下していた。

（7）血液资患 6

表11亿示すよ5に，再生不良性賽血，血友病， 鉄欠之性貧血では総力执よび非透析性カが低下， 血清無機燐の高いものがあつた。

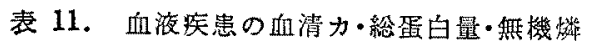

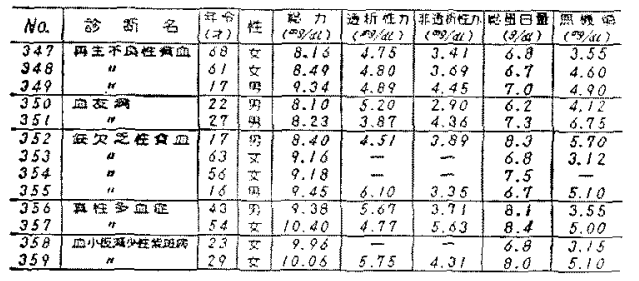

(8) 消化器疾患

表12に示すよ5に，急性坛よび慢性肝炎，胆石 症, 消化性潰瘍などでは血清総蛋白量, 総力に变 動なく，透析性力増加と非透析性力の低下が認め られた. 最近, 副甲状腺機能六進症と膵炎, 消化 性謴演が合併することが報告されているが消化性 潰瘍 18 例中 2 例が総力 10.51 よび $10.93 \mathrm{mg} / \mathrm{dl}$ を示し，また他の 2 例では透析性カだけが 6.26,

$5.96 \mathrm{mg} / \mathrm{dl}$ (総力 $9.75,10.10 \mathrm{mg} / \mathrm{dl}$ ) と高值を示 した。 そのち台血清無機燐は 1 例のみ $2.95 \mathrm{mg} / \mathrm{dl}$ であり，低燐血症を示した例はなかつた。

肝硬变症, 急性黄色肝萎縮症, 慢性膵炎では血 清総カの低下がみられた。旰硬変症では前述の癌

表 12. 消化署突患の血清カ・総蛋白是·無機燐

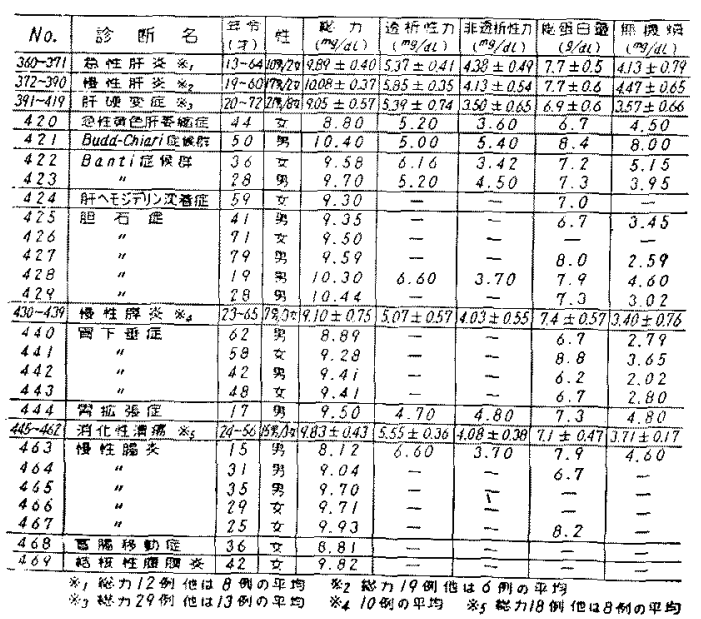

の如く総蛋白量，非透析性力が低下していたが， 癌より総蛋白量低下の少ない肝硬变症の方が非透 析性カの低下が著明であつた。だじし両者の血 清アルブミン量を比較すると肝硬燚症では平均 3.37 , 癌では平均 $3.90 \mathrm{~g} / \mathrm{dl}$ であり肝硬变症の 方が低かつた。肝硬变症で腹水貯留例恃 8 例あり $9.09,9.03 \mathrm{mg} / \mathrm{dl} の 2$ 例を除けばすべて血清総力低 值 $(8.70,8.66,8.65,8.568 .10,7.39 \mathrm{mg} / \mathrm{dl})$ を 示した．慢性萃炎では非透析性力の低下が認めら れたが血清総蛋白量括よび血清アルブミン（3.69 〜 4 $79 \mathrm{~g} / \mathrm{dl}$ ) の低下は認められなかつた。

(9) 衴経宛患

表13に示すよ5に交代性片麻痺 (No. 477) とて んかん（No. 480）の各1例の総力が減少していた 他, 片麻瘁を伴なう脳卒中の 2 例（No. 475，476） で総力高值を示したが血清與機燐は正常ですつ t.

（10）その他の疾患

表14の如く，重症筋然力症 7 例では非透析性力 が低下乙，周期性四肢麻痺の1例では総カと非透

表 13. 神経宛患の血清力・総蛋白量・無機燐

\begin{tabular}{|c|c|c|c|c|c|c|c|c|}
\hline No. & 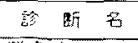 & $\begin{array}{l}\text { 돠 } \\
(\Rightarrow)\end{array}$ & 性 & $\begin{array}{l}10 \pi \\
(m y / a t)\end{array}$ & 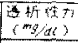 & 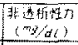 & 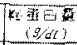 & 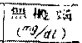 \\
\hline 470 & 20 & 45 & $B$ & 9.30 & - & - & - & $=$ \\
\hline 471 & " & 62 & $\frac{\text { Ts }}{74}-100$ & 9.47 & - & - & - & - \\
\hline 47.3 & 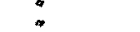 & 44 & $\begin{array}{l}\frac{9}{4}+ \\
9\end{array}$ & $\begin{array}{r}7.57 \\
10.40\end{array}$ & $\bar{z}$ & 二 & $\bar{z}$ & $\bar{z}$ \\
\hline$\$ 74$ & $\approx$ & 32 & F; & 10.75 & - & - & $=$ & $\bar{z}$ \\
\hline $4 \% 5$ & $a$ & 35 & 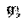 & 11.01 & - & - & 7.7 & 3.05 \\
\hline+46 & $*$ & $x^{3} 2$ & 9 & 11.25 & - & - & 7.1 & 4.40 \\
\hline $47 \%$ & $x_{1}+\mu_{1}$ & 39 & $y$ & 8.59 & $=$ & $=$ & 7.2 & \\
\hline 478 & $11 \mathrm{NDS}$ & 49 & 9 & 9.43 & -2 & - & 7.3 & 2.30 \\
\hline-479 & A & $\$ 1$ & $\%$ & 10.60 & 5.30 & 5.30 & $7 . ?$ & 6.60 \\
\hline 400 & $6 \alpha 2 \alpha$ & $\sqrt{4}$ & $x$ & 8.47 & - & - & B.2 & 3.30 \\
\hline 481 & $7^{\prime \prime}-7$ & 19 & 45 & 9.77 & $=$ & - & 6.5 & 4.21 \\
\hline$\frac{487}{483}$ & & 50 & 91 & 0.04 & $=$ & $=$ & $6 \cdot 1$ & 3.35 \\
\hline$\frac{484}{184}$ & 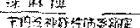 & $\frac{1}{31}$ & 3 & 10.33 & - & 二 & $\theta=4$ & 2.90 \\
\hline 485 & 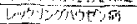 & st & $\frac{2 !}{2}$ & $\frac{9.69}{6} \cdot 9$ & $=$ & - & d. 9 & 3.35 \\
\hline 480 & 极 & $\frac{4}{52}$ & $\varphi_{1}$ & $\frac{9.93}{9.24}$ & 4.23 & $\frac{5.05}{-2}$ & 0.8 & 2.85 \\
\hline 407 & " & 49 & S3 & 0.49 & - & - & $\because 0$ & 4.95 \\
\hline 488 & " & 15 & of & 10.70 & - & - & 1.0 & $=$ \\
\hline
\end{tabular}

表 14. その他の涘患の血清カ・総蛋白喳・無㙨燐

\begin{tabular}{|c|c|c|c|c|c|c|c|c|}
\hline No. & 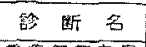 & $\begin{array}{l}\text { 然命 } \\
\text { ( } 31)\end{array}$ & 性 & $\begin{array}{l}\pi \\
(0, g / d i)\end{array}$ & $\begin{array}{l}\text { 透析 } \\
(m s / \alpha<)\end{array}$ & 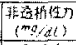 & 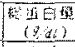 & 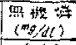 \\
\hline 489 & 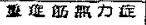 & 63 & 男 & 8.63 & 4.68 & 3.94 & 6.4 & 4.60 \\
\hline 49 & & 48 & 9 & 9.43 & 5,47 & 3.96 & $7, i$ & 3.55 \\
\hline 491 & $"$ & 20 & 女 & 9.43 & 4.99 & 4.44 & 7.4 & 4.05 \\
\hline 49 & a & 46 & sर & 9.62 & - & - & 8.3 & $3.6-5-1$ \\
\hline 49 & 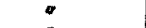 & 23 & 女 & 9.80 & 5.80 & 4.00 & 6.8 & 4.50 \\
\hline 494 & 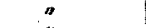 & 34 & 93 & 10.11 & $\overrightarrow{1}$ & - & 7.0 & 3.70 \\
\hline \multirow[t]{2}{*}{495} & " & $7 !$ & 9 & 10.34 & 6.14 & 4.20 & 7.4 & 3.35 \\
\hline & & 平. & 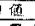 & $0.62 \pm 0.51$ & $542+057$ & $1+11 \pm 019$ & $7.0 \pm 04$ & $405 \pm 0.50$ \\
\hline 496 & 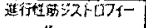 & 70 & 5 & 9.05 & 5.00 & 4.05 & 6.9 & $5 . \overline{75}$ \\
\hline $\begin{array}{l}497 \\
499\end{array}$ & " & $\begin{array}{l}61 \\
25\end{array}$ & 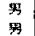 & $\begin{array}{r}4.75 \\
10.03\end{array}$ & $=$ & $\bar{z}$ & $\begin{array}{l}7.3 \\
8.0\end{array}$ & $\underline{-}$ \\
\hline 499 & 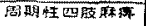 & 29 & 穷 & 8.86 & 5.17 & 3.25 & 7.4 & 3.31 \\
\hline 500 & $\ldots$ & 29 & 妿 & 10.07 & - & & & \\
\hline 501 & 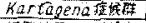 & 23 & s & 9.45 & 4.75 & 4.70 & 6.8 & 3.36 \\
\hline 502 & 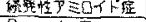 & 26 & 照 & -9.16 & 5.91 & 3.25 & 5.6 & 5.50 \\
\hline & PQget & 51 & 塄 & 8.56 & 5.74 & & & 12.40 \\
\hline 4 & ザルつイドージ & 52 & 女 & 9.92 & 6.45 & 2.47 & 6.5 & 4.15 \\
\hline
\end{tabular}



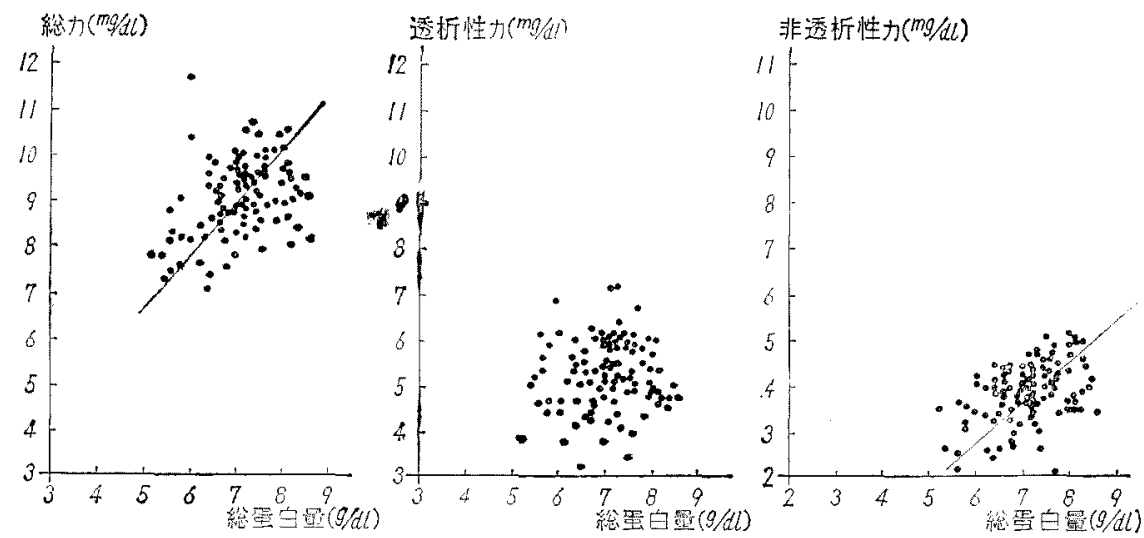

図 2. 血清総蛋白最と血清力の相闒関係
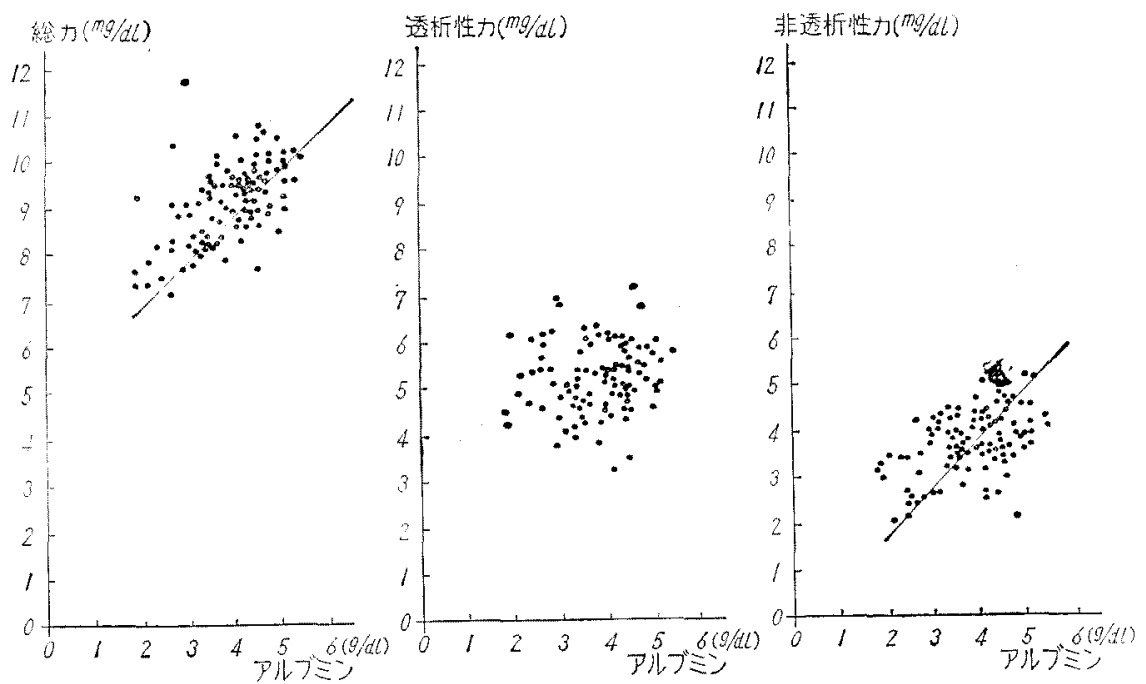

图 3. 血清アルブミンと血清力との相閶関係

析性カが低下したが，進行性筋ジストロフィー症 の3 例の総力は変動がなかつた。続発性アミロイ ド症, Paget 病, ザルコイドージスでは透析性力 は著明に增加し非透析性かが減少していた。

III. 血清総蛋白量执よび無機燐之総力, 透析 性力, 非透析力と口相関関係

表 1 に山げた 590 例の5ち蛋白分屑のわかつた

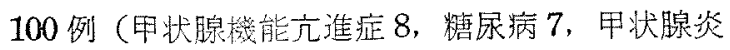
2, Conn 症候群, Cushing 症侯群, Sheehan 症侯 群, Chiari-Frommel 症侯群各 1, 癌 21, 慢性腎 炎 12 , 膠原病 5 , 高血圧症 5 , 心疾患 3 , 䆩血 3 , 血小板減少性紫斑病 1 , 䀒硬変症 8 , 慢性膵炎 7 ,
急性肝炎 6 , Banti 症候群 2 , 慢性肝炎 1 , 消化性 溃瘍 1，胃搪張症 1，重症筋䝷力症 2 扣よび周期 性四肢麻痻 1 (例)について 血清総蛋白量と総力, 透析性力，非透析性力との相関関係について，推 計学的に検討した結果，図 2 , 図 3 に示すよ 5 に 血清総蛋白量, 殊にアルブミン量と血清総カおよ び非透析性力との間にいずれも正の相関関係が認 わられた。しかし血清無機燐已総力，透析性力抏 よび非透析性カとの間には図 4 に示すようにいず れにも相関関係は認められなかつた。

\section{IV. 考 案}

元来, カの出納は副甲状腺ホルモンの支配下に 


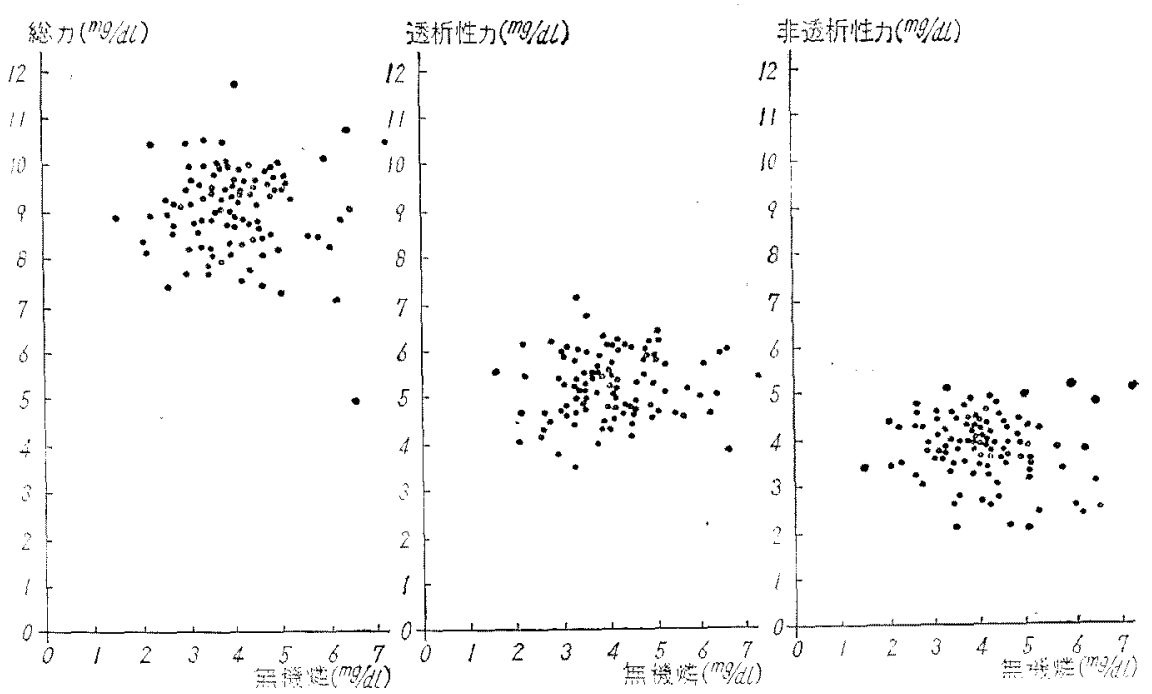

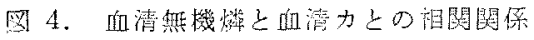

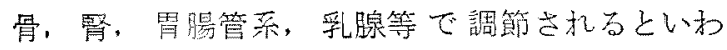
れ，一応副甲状腺ホルモンは骨からの力放出と腎

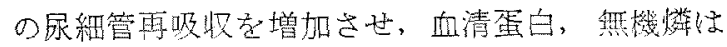
ビタミン D，血液 $\mathrm{pH} ， \mathrm{Mg}^{+}$その他のイオンなど

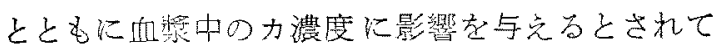
Wる.

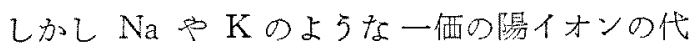
謝が最近急速に解明されつ〉あるのに比べると $\mathrm{Ca}, \mathrm{Mg}$ のような二価の陽イオンの代謝の研究に は古安り焦步が著しくないのが現状である。その 原因の主なるるとして測定方法の煩簡の差をあげ なければならない、すなわち，血清総力の湘定法は 1921年 Kramer \& Tisdall ${ }^{52}$ が苳酸アンモニウム による方法を，1925年には Clark \& Collip ${ }^{3)} か ゙ そ$ の变法を報告して以来次第に臨床に利用されるよ うになつた。しかしこの方法は操作が煩雑なため， その後も, EDTA法, 柳沢汢得等が考案されてき たが，終反応がみにくいとか，Mgサ干涉等记問題 があるため著者はClark \& Collip变法を用いた。 また血清透析性力の測定法については、コロジオ ン管で透析させる Toksoy \& Eser 法 ${ }^{97}$ や $4 \%$ 落 酸アソモニウムとの反応速度の差により分離する 柳沢法 ${ }^{103}$ ，柳沢法とEDTA 法とを利用しな岩脇ら の方法1などが報告されれているが，著者はカ代
謝の正確な成繢のつ攵重祊老必要亡する現段階に あつては，操作上の煩䧼さは古つても誤差の少な いToksoy＆Eser法を用いる方がよいと判断した。

徒来，健康人の血清彩力心一般に 9.0 11.0m /dl と幅が広いが著者の揵噔者86例についての血 清総力值は $9.80 \pm 0.21 \mathrm{mg} / \mathrm{dl}$ でずいら゙ん愊が狭 かつた．血清透析性力法総力 $065 \sim 70 \%{ }^{6)}$ とする 人もあるが，力エルの心臟を用いた McLean \& Hasting の実験》では㟟析性力の大部分はイオン 化力で総力の 40〜 50\%をしめると報告している。

Prasad \& Flink $の$ 值 $^{6)}$ 6大体これk近く, 総力 の45〜57\%であり，流動パラフィンで封入して測 定した A. S. Prasad ${ }^{6)}$ 《総力の52\%と報告した。

このよ5に研究者の間で少しずつ相䢔がみられる。 が著者の测定值は 4.39 5.15 mg/dl, 平均4.82士 $0.26 \mathrm{mg} / \mathrm{dl}$ で, 総力 $049.5 \%$ C McLean \& Hasting. Prasad \& Flink, A.S. Prasad らの値と一致して Wt.

一方，各種突患の血清総力の变動にかんしては 最近 J. E. Howard ${ }^{12)}$ が臨床的に高力血症を呈す る疾患として, カルシウム過剩投与, 副甲状腺譏 能穴進症, 甲状腺機能元進症, 昰性腫瘍, ザルコ イドージス, milk-alkali 症侯群，ビタミン $\mathrm{D}$ 過剩 症, 廃用性萎㬮, 特発性高力血症をあげ, 低力血 
症を呈する疾患として, 副甲状腺機能低下症, 偽 副甲状腚機能低下症, クル病, 慢性简不全, 高 窒素血定, 急性膆炎, 脂肪性下脷, アシドーシ ス，骨粗琹症，Cushing 症候群をあげている、著 者の症例の副甲状腺疾患では従来の報告通り、機 能六進で総力増加, 機能低下で減少を認めたが, 血清総蛋白量と関係なく透析性拈よび非透析性力 が総力と平行して增减していたことは，副甲状腺 ホルモンのカとの特翼性を示するのとして注目に 值する。

甲状腺機能元進症では osteoporosis のため高力 血症（最高 $19.9 \mathrm{mg} / \mathrm{dl}^{173}$ ) をきたすことがあると 報告されているが，血清総力がや〉高かつた著者 の4例では osteoporosis と関係なく透析性力晾よ び血清無機矮が高值を示した。渚者のCushing症 候群 1 例では osteoporosisが認められたが，甲状 腺機能九進症とは逆飞総力と透析性力が低下して $お り$, J.E. Howard の測定成績 ${ }^{12)}$ @ Garret らの ${ }^{47} \mathrm{Ca}$-steroid を用いたイヌの実験で steroid のた め尿中力排泄がえ進し血清力が低下すると報告し た成績 ${ }^{12)} と 一$ 致している。このことは血清力の変 動を論ずる時に osteoporosisのみを念頭に括くべ きでないことを示しているが，この考えをさらに 強くさせる事実はつぎの現象である。

最近文献的にも, 剖检上, 骨, 副甲状腺の变化が ないのに高力血症を呈する悪性腫瘍があるとの報 告が多くなりつ〉ある、著者らの癌患者72例中こ のよ5な意味でや〉高い血清総力值 $(10.50 \mathrm{mg} /$ d1）を呈した症例が 2 例みられたが，C. H. Plimpton $ら^{3)}$ は高力血症を呈した悪性腫㕫患者10例は 手術, 剖娭で骨, 副甲状腺に变化なく，その5ち 3 例は腫煌の除去によつてカ高値が正常化したと 述べている。この高力血症は骨破壊によるもので はなく，腫痛細胞よりある種の物質が分泌される 手のと考えられる ${ }^{3118}$ が B. Casthlemann らは腫 瘍からの副甲状腺ホルモン類似物質の抽出に失敗

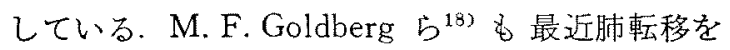
伴なつた腎癌患者で同様の意味で $18.0 \mathrm{mg} / \mathrm{dl} に$ 及ふ高力血症を認め, 死後, 腎・肺中の癌組織に
副甲状腺と同程度のホルモン活性を認めている。

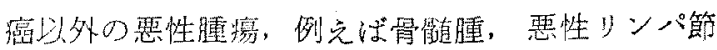
腫，白血病でも高力血症を示すことがあり、著 者の $19.83 \mathrm{mg} / \mathrm{dl}$ の高值を示したリンバ性白血病 (No.169) もその好例であり注意していればもつ と多いと考党られる。

血清力の低下する病気として前述の副甲状腺機 能低下症を除けば腎疾患が問題となる，系球体で 滤過される力は主としてイオン化カとされ，慢性 留炎で法尿中力排泄が過剩なため血清力が低下す

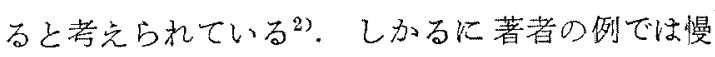
性腎炎，尿毒症ともに，むしろ非透析性力の低下 が著明で嵓つたし，血清総蛋白量の低下と, 総力 执よび非透析性力の低下とが正の相関を示してい るので血清蛋白量の低下がこの一因になつている と考党たい。さらに総力 $6.4,7.5 \mathrm{mg} / \mathrm{dl}$ でテタ ニーを和こした報告もあるのに，著者の症例で総 力 $7.5 \mathrm{mg} / \mathrm{dl}$ 以下の 5 例がいずれもデニーをお こさず测定できた透析性力が $4.0 \mathrm{mg} / \mathrm{dl}$ 以上であ つたことるこの考光と矛盾しないが，No. 204 のよ 5 に血清総力 5.8 , 透析性力 $3.2 \mathrm{mg} / \mathrm{dl}$ であって もテタニーを起こさない例もあるので，この説明 はそ5簡単なものではない。ただ，後者の説明と してKrane S. M. ${ }^{153}$ が透析性カの低下が徐々であ ると低力血症に対する tolerance を生じてテタニ 一を招こさないと述へていることを指摘して挌き たい，ところで文献によれば血清総蛋白量と血清 総力, 非透析性力との相関関係について，つとに McLean \& Hasting ${ }^{16)} \not j$ 正の相関を認めている ことは注目に值するが，著者の 100 例でもこの関 係を肯定できた。非透析性カは主として血清アル ブミンと結合しているといわれるが，総力の低い 著者の癌, 肝硬变症患者の中でも, 非透析性力の低 下は総蛋白よりも血清アルブミン低下のつよい肝 硬变症の方が著明であつた。沉発性紅斑性狼瘡で 総力の低下寸ることは従来 報告されていないよ5 であるが，本疾患もケーグロブリンの増加とアルブ ミンの減少がある点で McLean, 著者らの考方方 とよく一致している. 血友病 2 例の総力低下も疾 
固機転から考えて 興味深いが症例も少なく透析 性, 非透析性の点でも一致しないので今後の研究 にまた权ばならない。

粠苂でもしばしば力低下が認められ，これは血 清りパーゼの増加によつて, 血清脂肪酸が増加 し、これとカと結合してイオン化力が減少するた めと説明されている。しかし著者の例では透析性 力の变動は認められず，総力と非透析性力の低下 が認めら机た. Conn 症候群にみられるテタニー は細胞外了ルカロージスによるCaイオン低下によ ると説明されているが，著者の5例でも全般的に 血清総力和よび透析性力の低下が認められ，とく にテタニーを示した No. 39 で怯透析性カが 3.45 $\mathrm{mg} / \mathrm{dl}$ で 5 例中最低で, テタニーと透析性カ低下 との関倸を゙肯定せしぬる。

最近, 副甲状腺機能志進症と蓕炎, 消化性渱瘍 との合併症弥報告され゙興味を集めている。す

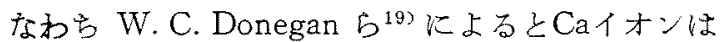
胃機能を刺激し，副甲状腺ホルモンの注射は胃液 分泌をたかめると報告して持り，水本203はラット に副甲状腺ホルモンを注射して肉眼的な線状潰湟 を認めている。しかし Boy Frame 消化性潰㿑中 4 例に副甲状腺機能六進症を索之め たのみで，残りの296 例中 5 例が高力血症を呈し たが，血清無機燐，燐再吸収率ともに異常を認め なかつた，著者の消化性潰演18例中 2 例で血清総 カが $10.51,10.93 \mathrm{mg} / \mathrm{dl}$ とや高值であつたが 低燐血症はなく，消化性潰湯では一般に透析性力 が高値を示した。

以上を要約するに各種疾患の透析性力にか九し

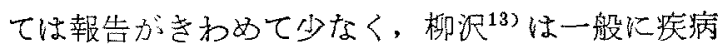
が重症になると透析性かが低下すると報告してい る，著者の成績では，平均值でみる限り透析性カ は甲状腺譏能元准症，糖尿病，癌，骨檤性白血 病, 高血王症, 肺結核, 急性および慢性肝炎, 肝 硬変症, 消化性潰瑒で增加し, 慢性腎炎, 慢性膵 炎, 重症筋無力症等で变動なく，尿毒症, Conn 症候群では低下していた，非透析性力は上記疾患 の5ち，変動のないConn 症候群を除いた他の笑
患と膠原病では低下していた。すなわち、一般に 重症な疾患ではむしろ非透析性力の低下が著しい 感があつた。

つぎに血清無機燐と力とは一定の $\mathrm{pH}$ では逆相 関を示すといわれているが，著者の 100 例につい ては，相関関係を証明できなからた。慢性腎炎， 尿毒症では血清無機燐が增加し，総力が娍少した が，推計学的には逆相関関係を証明できなかつ た。

以上，血清総力，透析性力，非透析性力 3゙各種 疾患で变動することを示したが，その中に怯徉来 の報告にみられない上らな成績も古り，このよう な力代謝異常に対して，副甲状腺その他の器官が 如何に関与するかは今後の研究にまた稀ばなら ない.

\section{V. 結 論}

健康者86例, 各種疾患 504 例の血清力, 総蛋白 量，無機燐を湘定してつぎの結論を得た。

1）踭康者の血清総力は $9.80 \pm 0.21$, 透析性 力 $4.82 \pm 0.20$, 非透析性力 $4.92 \pm 0.21 \mathrm{mg} / \mathrm{dl}$, 総 蛋白量 $7.6 \pm 0.3 \mathrm{~g} / \mathrm{dl}$, 焎機燐 $3.37 \pm 0.37 \mathrm{mg} / \mathrm{dl}$ であつた。

2) 副甲状腺機能六進症では総力, 透析性力, 非透析性カともに高く，副甲状腺機能低下症では ともに低下していた。

甲状腺機能六進症, 糖尿病, 急性括よび慢性肝 炎，消化性潰演，肺結核などでは平均して総力に 著变なく，透析性力が増加，非透析性力が減少し ていたが，甲状腺譏能六淮症，消化性潰瘍の中に は総力が高値を示す例があつた。

3）慢性腎炎，尿毒症で学，総力，非透析性力 が低下し，総蛋白の低下と正の相関がみられたが 無譏燐との相関はなかった。

4) 癌, 肝硬変症, 慢性膵炎では総力, 非透析 性カが低下していた，悪性腫疸の中には総力が高 值を示するのがあり、リンパ性白血病の 1 例で は19.83mg/dl であつた。

5) 沉発性紅斑性狼瘡，血友病では，総力が低 下し Conn 症候群では総力, 透析性カが低下し, 
中でもテタニ一症状を呈した症例では，透析性力 の低下が著明であつた。

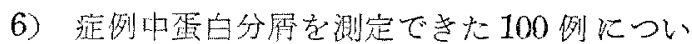
て検討した結舆，血清総秀白量，ことに血清了ル ブミンは，血清総力，非䢪析性力との間に相関関 係を認めたが，血清無機燐とは相関関係を認めな 加つた。

\section{参势文献}

1) Rasmussen, H., and Craig, L. C.: I. Amer. chem. Soc., 81:5003, $1959 . \quad$-2) Howard, Rasmussen, : Amer. J. Med., 30 (1) : 112 127, 1961. -3) C. H. Plimpton: Amer. J. Med., 21, (11): 750 759, 1956. -4) Boy, Frame.: Arch. intern. Med., 105 (4): 536 541, 1960. -5) Klamer, B., and Tisdall, F. F.: J. B. C., 48: 223 232, 1921. -6) A. S. Prasad: Arch. intern. Med., 105 (4): 560 571, $1960 . \quad-7)$ McLean, and
Hasting: J. B. C., $107: 351 \sim 370,1934,-8)$ E. P. Clark, and J. B. Collip: I. B. C., $63: 461 \sim 464$, 1921. -9) von G. Toksoy, and S. Eser; Helv. med. Aata (Suppl. 7), 8:77 82, $1941 . \quad-10$ )

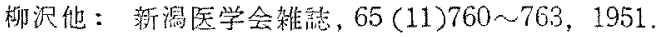
-11）岩脇：十全医学会教誌，61(1)：1１1，1959. -12) J. E. Howard: Medicine, $42(1): 25 \sim 46$,

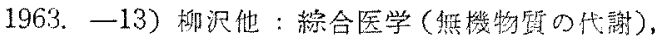
15, (15) : 377 389, $1958 . \quad-14)$ Hodgkinson A.: Lancet, II (7095): 157 160, 1959, -15) Krane, S. M. : J. Amer. med. Ass., 178 (5):472 $\sim 475,1961$. -16) McLean, and Hasting: J.B. C., $108: 285 \sim 322,1935 . \quad$-17) T. S. Danowski : Clin. Endocr, 3: 165 166, Baltimore, 1962. -18) N. F. Goldberg et al. : Amer. J. Med., 36 (5): 805 814. 1964. -19) W. L. Donegan: Gastroenterology, $38(5): 750 \sim 759,1960 .-20)$ 水本 他：日本内分论学会雑誌，39（3）：282，1963. 